\title{
CL316243 Induces Phosphatidylinositol 3,4,5-triphosphate Production in Rat Adipocytes in an Adenosine Deaminase-, Pertussis Toxin-, or Wortmannin-Sensitive Manner
}

\author{
Y. OHSAKA ${ }^{1,3}$, Y. NOMURA ${ }^{2,3}$
}

${ }^{1}$ Department of Pharmacology, Faculty of Pharmaceutical Sciences, Chiba Institute of Science, Choshi, Chiba, Japan, ${ }^{2}$ Yokohama College of Pharmacy, Yokohama, Kanagawa, Japan, ${ }^{3}$ Department of Pharmacology, Faculty of Pharmaceutical Sciences, Hokkaido University, Sapporo, Hokkaido, Japan

Received August 5, 2015

Accepted February 12, 2016

On-line March 15, 2016

\section{Summary}

The effect of $\beta_{3}$-adrenoceptor ( $\beta_{3}-A R$ ) agonists on adipocytes treated or not treated with signaling modulators has not been sufficiently elucidated. Using rat epididymal adipocytes (adipocytes) labeled with [ $\left.{ }^{32} \mathrm{P}\right]$ orthophosphate, we found that treatment with the selective $\beta_{3}-A R$ agonist CL316243 (CL; $\left.1 \mu \mathrm{M}\right)$ induces phosphatidylinositol (PI) 3,4,5-triphosphate (PI[3,4,5] $\left.\mathrm{P}_{3}\right)$ production and that this response is inhibited by adenosine deaminase (ADA, an adenosine-degrading enzyme; $2 \mathrm{U} / \mathrm{ml}$ ), pertussis toxin (PTX, an inactivator of inhibitory guaninenucleotide-binding protein; $1 \mu \mathrm{g} / \mathrm{ml}$ ), or wortmannin (WT, a PI-kinase inhibitor; $3 \mu \mathrm{M})$. The results showed that $\mathrm{CL}$ induced $\mathrm{PI}(3,4,5) \mathrm{P}_{3}$ production in intact adipocytes and that this production was affected by signaling modulators. Taken together, our findings indicate that $\mathrm{CL}$ produces $\mathrm{PI}(3,4,5) \mathrm{P}_{3}$ in an ADAsensitive, PTX-sensitive, or WT-sensitive manner and will advance understanding of the effect of $\beta_{3}$-AR agonists on adipocytes.

\section{Key words}

Adipocytes • CL316243 (disodium $(R, R)$-5-[2-[[2-(3-chlorophenyl) -2-hydroxyethyl]-amino]propyl]-1,3-benzodioxole-2,2-dicarboxylate) • Phosphatidylinositol 3,4,5-triphosphate

\section{Corresponding author}

Y. Ohsaka, Chiba Institute of Science, 15-8 Shiomi-cho, Choshi, Chiba 288-0025, Japan. E-mail: y-ohsaka@live.jp; y-ohsaka@cis.ac.jp
Treatment of adipocytes with $\beta_{3}$-adrenoceptor $\left(\beta_{3}\right.$-AR) agonists, including CL316243 (CL), induces various responses, including glucose transport and protein-kinase B phosphorylation (PKB activation) in a signaling modulator-sensitive manner (Ohsaka et al. 1998, Zmuda-Trzebiatowska et al. 2007). Polymorphic studies have indicated that signaling molecules associated with $\beta_{3}$-AR can be targeted to improve adipocyte dysregulation (Arner and Hoffstedt 1999). However, the effect of $\beta_{3}$-AR agonists on adipocytes, including those treated with signaling modulators, has not been fully elucidated.

Phosphatidylinositol (PI) 3,4,5-triphosphate $\left(\mathrm{PI}[3,4,5] \mathrm{P}_{3}\right)$ is a component of the PI 3-kinase-related pathway and has been shown to activate PKB (Walker et al. 1998). Additionally, expression of a $\mathrm{PI}(3,4,5) \mathrm{P}_{3^{-}}$ responsive kinase in rat epididymal adipocytes (adipocytes) induces an insulin (INS)-responsive glucose transport-related response (Standaert et al. 1997). PI 3-kinase activation is induced in adipocytes treated with CL as well as INS (Ohsaka et al. 2014). In a previous study, $\mathrm{PI}(3,4,5) \mathrm{P}_{3}$ was produced by INS treatment $(0.1 \mu \mathrm{M})$, which peaked at about $1 \mathrm{~min}$, in adipocytes in a signaling modulator (e.g. wortmannin [WT])-sensitive manner (Takasuga et al. 1999). However, it is unclear whether CL treatment produces phosphoinositides in intact adipocytes. The effect of CL treatment for $1 \mathrm{~min}$ on $\mathrm{PI}(3,4,5) \mathrm{P}_{3}$ production is 
unknown.

Adenosine is released from adipocytes and degraded in adenosine deaminase (ADA; $2 \mathrm{U} / \mathrm{ml}$, $<10 \mathrm{~min}$ )-treated adipocytes (Shirakura and Tokumitsu 1990). Adipocyte membranes treated with an adenosinereceptor agonist modulate the inhibitory guaninenucleotide-binding $(G)$ protein $G_{i}$ which can be affected by pertussis toxin (PTX) (Mitchell et al. 1989, Soeder et al. 1999). In addition, WT treatment (from 0.1 to $<10 \mu \mathrm{M})$ inactivates the kinases that produce PI 3- and PI 4-monophosphates (Okada et al. 1994). Previous studies showed that adipocytes treated with ADA (2 U/ml, $30 \mathrm{~min})$, PTX $(0.2 \mu \mathrm{g} / \mathrm{ml}, 180 \mathrm{~min})$, or WT $(0.1 \mu \mathrm{M}, 10 \mathrm{~min})$ exhibit altered responses to $\beta_{3}$-AR agonists (0.01-100 $\mu \mathrm{M}, 10-30 \mathrm{~min})$ (Chaudhry et al.
1994, Ohsaka et al. 1997, 1998, Zmuda-Trzebiatowska et al. 2007), including ADA- or PTX-sensitive alteration of $\beta_{3}$-AR agonist-induced adenosine $3^{\prime}, 5^{\prime}$-cyclic monophosphate (cAMP) accumulation. It is unclear whether CL produces $\mathrm{PI}(3,4,5) \mathrm{P}_{3}$ in an ADA-, PTX-, or WT-sensitive manner.

To investigate the effect of $\beta_{3}$-AR agonists on signaling modulator-treated or -untreated adipocytes, we examined whether treatment with CL $(1 \mu \mathrm{M}$; Lederle Laboratories, Wayne, $\mathrm{NJ})$ for 1 min produces $\mathrm{PI}(3,4,5) \mathrm{P}_{3}$ and whether this response is affected by treatment with ADA (2 U/ml, 10 min; Sigma-Aldrich Co., St. Louis, MO), PTX ( $1 \mu \mathrm{g} / \mathrm{ml}, 60 \mathrm{~min}$; Kaken Pharmaceutical Co., Tokyo, Japan), or WT ( $3 \mu \mathrm{M}, 1 \mathrm{~min}$; Kyowa Hakko Kogyo Co., Tokyo, Japan). a



d

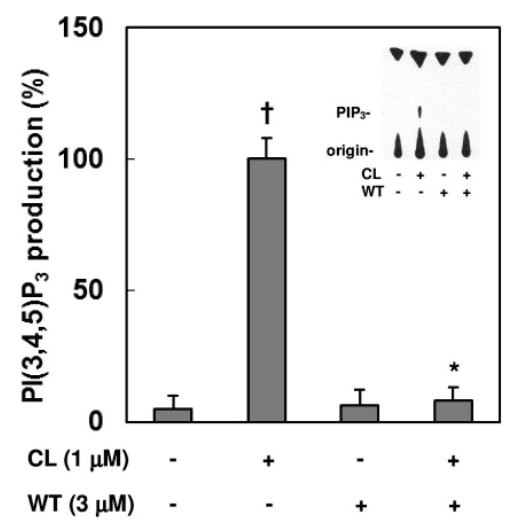

b

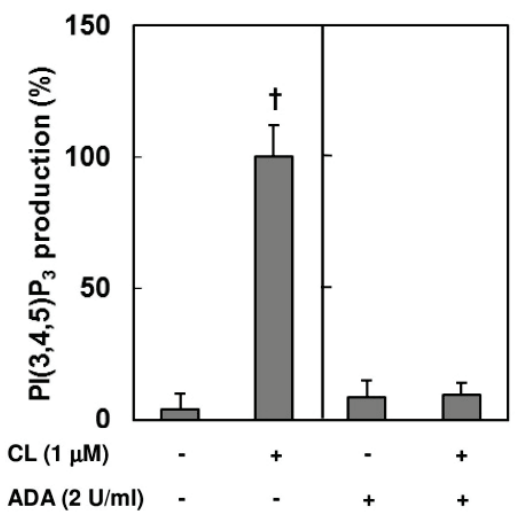

e

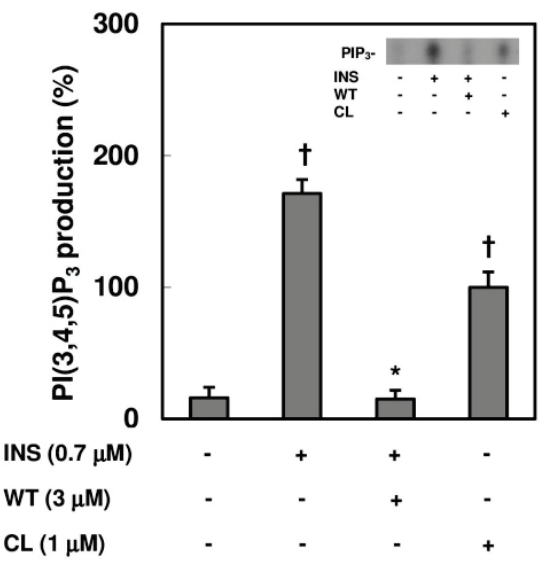

C



f

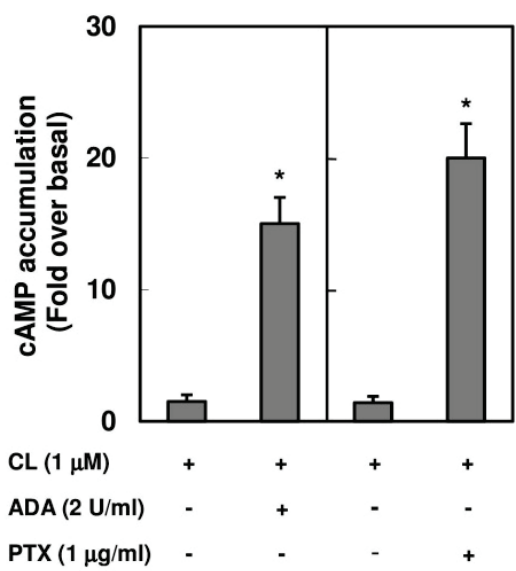

Fig. 1. Effect of $\mathrm{CL}$ alone or in combination with $\mathrm{ADA}$, $\mathrm{PTX}$ or $\mathrm{WT}$ on $\mathrm{PI}(3,4,5) \mathrm{P}_{3}$ production in adipocytes. [ ${ }^{32} \mathrm{P}$ ]orthophosphate-labeled adipocytes that were treated or not treated with ADA $(2 \mathrm{U} / \mathrm{ml}, 10 \mathrm{~min})$ or PTX $(1 \mu \mathrm{g} / \mathrm{ml}, 60 \mathrm{~min})$ were incubated for $1 \mathrm{~min}$ with or without $\mathrm{CL}\left(1 \mu \mathrm{M}\right.$; a-c). In addition, $\left[{ }^{32} \mathrm{P}\right.$ ]orthophosphate-labeled adipocytes treated with or without WT $(3 \mu \mathrm{M}, 1$ min) were incubated for 1 min with or without $\mathrm{CL}$ (d and $\mathbf{e})$ or INS $(0.7 \mu \mathrm{M}$; e). Furthermore, adipocytes treated or not treated with ADA or PTX were incubated for 10 min with or without $\mathrm{CL}(\mathbf{f})$. The radioactivity of $\mathrm{PI}(3,4,5) \mathrm{P}_{3}\left(\mathrm{PIP}_{3}\right)$ that was separated by TLC and the accumulation of cAMP in adipocytes were determined. Values are presented as means \pm standard deviation of 3 or 4 experiments. Autoradiographic images represent typical results. The results were analyzed using analysis of variance with Scheffe's test or unpaired Student's $t$-test. $+P<0.05$ vs. cells treated without agents (b-e). $* P<0.05$ vs. cells treated with $\mathrm{CL}$ alone (d and $\mathbf{f})$ or INS (e). 
Adipocytes $\left(10^{6}\right.$ cells $\left./ \mathrm{ml}\right)$ were prepared from rat epididymal adipose tissues as described previously (Ohsaka et al. 2014). Animal experiments, which were approved by the institutional review board, were conducted in accordance with the guidelines established by the Japanese Association for Laboratory Animal Science (JALAS) (JALAS 1987). The adipocytes were incubated for $2 \mathrm{~h}$ in phosphate-free Krebs-Ringer bicarbonate buffer containing $3 \%$ bovine serum albumin (Sigma-Aldrich Co.) in the presence of carrier-free $\left[{ }^{32} \mathrm{P}\right]$ orthophosphate (DuPont NEN, Boston, MA) at $37^{\circ} \mathrm{C}$. $\left[{ }^{32} \mathrm{P}\right]$-labeled adipocytes treated with or without agents were immediately separated from the medium by centrifugation at $500 \mathrm{xg}$ for $20 \mathrm{~s}$, and phospholipids were extracted and separated by thin-layer chromatography (TLC) in a solution of chloroform/acetone/methanol/ acetic acid/water (80:30:26:24:14, v/v) as described previously (Arcaro and Wymann 1993). The radioactivity of $\mathrm{PI}(3,4,5) \mathrm{P}_{3}$ was detected and quantified using a Fuji BAS2000 Bioimaging Analyzer (Fuji Photo Film Co., Tokyo, Japan).

To confirm the function of isolated adipocytes, we examined whether treatment with INS $(0.7 \mu \mathrm{M}$, 1 min; Sigma-Aldrich Co.) produces $\mathrm{PI}(3,4,5) \mathrm{P}_{3}$ in a WT-sensitive manner and whether ADA or PTX treatment alters $\mathrm{CL}(1 \mu \mathrm{M}, 10 \mathrm{~min})$-induced cAMP accumulation; cAMP accumulation was determined as described previously (Shirakura and Tokumitsu 1990). Treatment of the adipocytes with INS induced WT-sensitive $\mathrm{PI}(3,4,5) \mathrm{P}_{3}$ production (Fig. 1e), and ADA or PTX treatment altered CL-induced cAMP accumulation (Fig. 1f).

$\mathrm{PI}(3,4,5) \mathrm{P}_{3}$ is produced from $\mathrm{PI} 4,5-$ bisphosphate $\left(\mathrm{PI}[4,5] \mathrm{P}_{2}\right)$ in a PI 3-kinase p85 regulatory subunit-containing immunocomplex (Kelly and Ruderman 1993). In G-protein subunit $\beta$ (G $\beta$ ) antibody immunoprecipitates, $C L$ treatment increases the PI 3-kinase p85 subunit level and phosphorylates the 3'-position of the inositol ring (Ohsaka et al. 2014). In addition, $\mathrm{PI}(3,4,5) \mathrm{P}_{3}$ is dephosphorylated by a $\mathrm{PI}(3,4,5) \mathrm{P}_{3}$ phosphatase in vitro, and this dephosphorylation is enhanced by $\mathrm{PI}(4,5) \mathrm{P}_{2}$ (Campbell et al. 2003). As shown in Figure 1a-e, CL treatment produced $\mathrm{PI}(3,4,5) \mathrm{P}_{3}$. This response is presumed to be regulated by a PI or phosphoPI kinase(s) and/or a phospho-PI phosphatase(s). Production of $\mathrm{PI}(3,4,5) \mathrm{P}_{3}$, which is produced by INS, was induced in CL-treated intact adipocytes.

$\mathrm{PI}(3,4,5) \mathrm{P}_{3}$ is able to activate $\mathrm{PKB}$ isoforms (Walker et al. 1998), including PKB- $\alpha /-\beta$ (which can be phosphorylated). Additionally, treatment of adipocytes with $\mathrm{PI}(3,4,5) \mathrm{P}_{3}$ activates the protein-kinase $\mathrm{C}$ (PKC) isoform PKC- $\zeta$ (Standaert et al. 1997). The number of glucose transporters (GLUT4) in the plasma membrane (PM) is increased by expression of PKB- $\alpha$ (Tanti et al. 1997) or PKC- $\zeta$ (Standaert et al. 1997). CL-induced $\mathrm{PI}(3,4,5) \mathrm{P}_{3}$ production may regulate activation of $\mathrm{PKB}-\alpha$ and/or $-\beta$ the expression of which is observed in adipocytes (Walker et al. 1998) and PKC- $\zeta$ and may induce PM GLUT4 expression.

Adipocytes have the $\mathrm{G}_{\mathrm{i}}$-coupled A1 adenosinereceptor (Burnstock 2014). The G-protein subunit $\mathrm{G} \alpha$ of $\mathrm{G}_{\mathrm{i}} 1$ or $\mathrm{G}_{\mathrm{i}} 2$ is modified by PTX (Mitchell et al. 1989); PTX inhibits receptor signaling-induced G-protein dissociation of the $\mathrm{G} \alpha$ and $\mathrm{G} \beta \gamma$ subunits (Katada et al. 1984). ADA or PTX treatment did not induce CL-induced $\mathrm{PI}(3,4,5) \mathrm{P}_{3}$ production (Fig. 1a-c). The CL-induced $\mathrm{PI}(3,4,5) \mathrm{P}_{3}$ production may be regulated by adenosine-sensitive molecules including the A1 adenosine-receptor and by a PTX-sensitive $G_{i}$ isoform(s). Adipocytes express the PI 3-kinase isoforms p85/p110- $\alpha /$ p110- $\beta$ (Ohsaka et al. 2014 and Discussion section therein) and PI 4-kinase (Okada et al. 1994). The $\mathrm{p} 85 / \mathrm{p} 110-\beta$ isoform is activated by G $\beta \gamma$ in vitro (Hazeki et al. 1998). WT inactivates these kinases. In Figure 1d, CL-induced $\mathrm{PI}(3,4,5) \mathrm{P}_{3}$ production was inhibited by WT; such an inhibitory effect was not observed when another response (lipolysis) was measured (data not shown). Adipocyte membranes treated with $\beta_{3}$-AR agonists modulate $G$ proteins (Soeder et al. 1999), including $G_{i}$ which can regulate p85 complex formation in G $\beta$ antibody immunoprecipitates (Ohsaka et al. 2014). CL-induced $\mathrm{PI}(3,4,5) \mathrm{P}_{3}$ production may be regulated by WT-sensitive PI kinases, including a PI 3-kinase isoform of p85/p110.

In this study, CL induced the production of $\mathrm{PI}(3,4,5) \mathrm{P}_{3}$ in intact adipocytes, and this production was affected by signaling modulators. Our findings indicate that $\mathrm{CL}$ produces $\mathrm{PI}(3,4,5) \mathrm{P}_{3}$ in an ADA-sensitive, PTX-sensitive, or WT-sensitive manner and will advance understanding of the effect of $\beta_{3}$-AR agonists on adipocytes.

\section{Conflict of Interest}

There is no conflict of interest.

\section{Acknowledgements}

We thank Dr. Y. Tokumitsu (Hokkaido University, Japan) for helpful advice on the measurement of cAMP. 


\section{References}

ARCARO A, WYMANN MP: Wortmannin is a potent phosphatidylinositol 3-kinase inhibitor: the role of phosphatidylinositol 3,4,5-trisphosphate in neutrophil responses. Biochem J 296: 297-301, 1993.

ARNER P, HOFFSTEDT J: Adrenoceptor genes in human obesity. J Intern Med 245: 667-672, 1999.

BURNSTOCK G: Purinergic signalling in endocrine organs. Purinergic Signal 10: 189-231, 2014.

CAMPBELL RB, LIU F, ROSS AH: Allosteric activation of PTEN phosphatase by phosphatidylinositol 4,5-bisphosphate. J Biol Chem 278: 33617-33620, 2003.

CHAUDHRY A, MACKENZIE RG, GEORGIC LM, GRANNEMAN JG: Differential interaction of $\beta_{1^{-}}$and $\beta_{3}$-adrenergic receptors with $G_{i}$ in rat adipocytes. Cell Signal 6: 457-465, 1994.

HAZEKI O, OKADA T, KUROSU H, TAKASUGA S, SUZUKI T, KATADA T: Activation of PI 3-kinase by G protein $\beta \gamma$ subunits. Life Sci 62: 1555-1559, 1998.

JALAS: Guidelines on animal experimentation (in Japanese). Exp Anim 36: 285-288, 1987.

KATADA T, NORTHUP JK, BOKOCH GM, UI M, GILMAN AG: The inhibitory guanine nucleotide-binding regulatory component of adenylate cyclase. Subunit dissociation and guanine nucleotide-dependent hormonal inhibition. J Biol Chem 259: 3578-3585, 1984.

KELLY KL, RUDERMAN NB: Insulin-stimulated phosphatidylinositol 3-kinase. J Biol Chem 268: 4391-4398, 1993.

MITCHELL FM, GRIFFITHS SL, SAGGERSON ED, HOUSLAY MD, KNOWLER JT, MILLIGAN G: Guaninenucleotide-binding proteins expressed in rat white adipose tissue. Identification of both mRNAs and proteins corresponding to $\mathrm{G}_{\mathrm{i}} 1, \mathrm{G}_{\mathrm{i}} 2$ and $\mathrm{G}_{\mathrm{i}} 3$. Biochem J 262: 403-408, 1989.

OHSAKA Y, TOKUMITSU Y, NOMURA Y: Suppression of insulin-stimulated phosphatidylinositol 3-kinase activity by the $\beta_{3}$-adrenoceptor agonist CL316243 in rat adipocytes. FEBS Lett 402: 246-250, 1997.

OHSAKA Y, MURAKAMI T, YOSHIDA T, TOKUMITSU Y: Comparison of atypical $\beta_{3}$-adrenoceptor agonists with their respective metabolic activities in rat white adipocytes. Jpn J Pharmacol 77: 41-51, 1998.

OHSAKA Y, NISHINO H, NOMURA Y: Adipose cells induce phospho-Thr-172 AMPK production by epinephrine or CL316243 in mouse 3T3-L1 adipocytes or MAPK activation and G protein-associated PI3K responses induced by CL316243 or aluminum fluoride in rat white adipocytes. Folia Biol (Praha) 60: 168-179, 2014.

OKADA T, KAWANO Y, SAKAKIBARA T, HAZEKI O, UI M: Essential role of phosphatidylinositol 3-kinase in insulin-induced glucose transport and antilipolysis in rat adipocytes. J Biol Chem 269: 3568-3573, 1994.

SHIRAKURA S, TOKUMITSU Y: Insulin-stimulated glucose transport regulated by adenylyl cyclase system in rat adipocytes. Comp Biochem Physiol 96A: 503-509, 1990.

SOEDER KJ, SNEDDEN SK, CAO W, DELlA ROCCA GJ, DANIEL KW, LUTTRELL LM, COLLINS S: The $\beta_{3}$-adrenergic receptor activates mitogen-activated protein kinase in adipocytes through a $\mathrm{G}_{\mathrm{i}}$-dependent mechanism. J Biol Chem 274: 12017-12022, 1999.

STANDAERT ML, GALLOWAY L, KARNAM P, BANDYOPADHYAY G, MOSCAT J, FARESE RV: Protein kinase $\mathrm{C}-\zeta$ as a downstream effector of phosphatidylinositol 3-kinase during insulin stimulation in rat adipocytes. J Biol Chem 272: 30075-30082, 1997.

TAKASUGA S, KATADA T, UI M, HAZEKI O: Enhancement by adenosine of insulin-induced activation of phosphoinoitide 3-kinase and protein kinase B in rat adipocytes. J Biol Chem 274: 19545-19550, 1999.

TANTI J-F, GRILLO S, GRÉMEAUX T, COFFER PJ, VAN OBBERGHEN E, LE MARCHAND-BRUSTEL Y: Potential role of protein kinase $\mathrm{B}$ in glucose transporter 4 translocation in adipocytes. Endocrinology 138: 2005-2010, 1997.

WALKER KS, DEAK M, PATERSON A, HUDSON K, COHEN P, ALESSI DR: Activation of protein kinase B $\beta$ and $\gamma$ isoforms by insulin in vivo and by 3-phosphoinositide-dependent protein kinase-1 in vitro: comparison with protein kinase B $\alpha$. Biochem J 331: 299-308, 1998.

ZMUDA-TRZEBIATOWSKA E, MANGANIELLO V, DEGERMAN E: Novel mechanisms of the regulation of protein kinase B in adipocytes; implications for protein kinase A, Epac, phosphodiesterases 3 and 4 . Cell Signal 19: 81-86, 2007. 